\title{
Viral infections of Apis mellifera: its importance, dynamics, diagnostics and treatment opportunities
}

\author{
Marta Matusiewicz ${ }^{1}$, Ewa Margas ${ }^{1}$, Maciej P. MaZureK ${ }^{1}$, \\ Luiza Wesolowska ${ }^{2}$, AgNieszKa Belter ${ }^{2}$, MirosŁaWa SKuPińska ${ }^{2 *}$ \\ ${ }^{1}$ Pure Biologics, Wrocław, Poland \\ ${ }^{2}$ BioScientia, Poznań, Poland
}

\begin{abstract}
Honey bees (Apis mellifera) play a crucial function in terrestrial ecosystems by maintaining floral biodiversity and providing sustainable agriculture through pollination. Bees affect 35\% of the world's crop production, hence, they are essential for economic sustainability, agriculture and food security. The economic value of pollination by bees goes beyond agricultural production. An important role of bees is pollination of the plants that provide food to the wild animals, and this is part of the proper functioning of the ecosystem. On the one hand Apis mellifera has great adaptive potential and it may be found in highly diverse climates almost everywhere in the world, but on the other hand bees are under constant threat by numerous pathogens including bacteria, viruses, fungi, Microsporidia, mites and insects. Other stress factors include environmental change-related stresses, pesticides, malnutrition and migratory beekeeping. The interactions among these, along with possibly other unknown factors, are causing widespread decline in honey bee populations - Colony Collapse Disorder (CCD) syndrome. Viruses are the most recent and still poorly investigated pathogens of the honey bees. Simultaneously, Varroa destructor mites and viruses are currently the high-profile suspects in collapsing bee colonies. Varroa acts as a vector for a range of RNA viruses of honey bees which are transferred when the mite feeds on hemolymph from the developing pupa. This publication aims to present an overview of the most important honey bee viruses, their diagnostics methods and treatment opportunities with emphasis on the most common and devastating viruses from Dicistroviridae and Iflaviridae families.
\end{abstract}

Key words: viruses, Apis mellifera, Colony Collapse Disorder, diagnostics methods

\section{Viral infection of Apis mellifera}

Pathogens affecting honey bees can be divided into three groups: ectoparasites, predators, and endoparasites. Ectoparasites include insects and mites such as $V a r-$ roa mite, wax moths (Achroia grisella), bee lice (Braula coeca), and tropilaelaps mite (Tropilaelaps spp.). Predators, e.g., small hive beetle (Aethina tumida) and Vespa velutina, prey on honey bees. Endoparasites live within the host body and these include bacteria, fungi, Microsporidia, viruses, and mites such as tracheal mites (Sammataro et al., 2000).

Currently there are 24 viruses identified in honey bees (Table 1) (Bailey and Ball, 1991; Ribière et al., 2008). Most of these viruses have been discovered in the 1960-1980s, while recent findings are mostly from mass sequencing of RNA and DNA from whole bee extracts (Fujiyuki et al., 2004; Cox-Foster et al., 2007; Cornman et al., 2010; Runckel et al., 2011). Some of the viruses are so closely related that they can be regarded as members of a single species complex (DWV/VDV1/EBV; ABPV/KBV/IAPV; SBV/TSBV; BVX/BVY, and LSV-1/LSV-2) (De Miranda et al., 2013). Most of these viruses have been detected only in honey bees, while a few have been identified in other bee species and ants as well.

Almost all viruses associated with honey bee infection have single-stranded RNA genomes. The only exceptions are Apis mellifera filamentous virus (AmFV) and Apis iridescent virus (AIV), which have a DNA genome. The most commonly studied honey bee RNA viruses

\footnotetext{
*Corresponding author: BioScientia, ul. Ogrodowa 2/8, 61-820 Poznań, Poland; e-mail: mirka@bioscientia.pl
} 
Table 1. Physical properties of the currently known honey bee viruses (adapted from Bailey and Ball (1991))

\begin{tabular}{|c|c|c|c|c|c|}
\hline Virus & Shape & Size & Capsid proteins & $\begin{array}{l}\text { Nucleic } \\
\text { acid }\end{array}$ & Genome size \\
\hline \multicolumn{6}{|c|}{ Dicistroviridae } \\
\hline Acute bee paralysis virus (ABPV) & Icosahedral & $30 \mathrm{~nm}$ & $35-9-33-24 \mathrm{kDa}$ & ssRNA & $9.5 \mathrm{~kb}$ \\
\hline Kashmir bee virus (KBV) & Icosahedral & $30 \mathrm{~nm}$ & $37-6-34-25 \mathrm{kDa}$ & ssRNA & $9.5 \mathrm{~kb}$ \\
\hline Israeli acute paralysis virus (IAPV) & Icosahedral & $30 \mathrm{~nm}$ & $35-7-33-26 \mathrm{kDa}$ & ssRNA & $9.5 \mathrm{~kb}$ \\
\hline Blackk queen cell virus (BQCV) & Icosahedral & $30 \mathrm{~nm}$ & $31-14-29-30 \mathrm{kDa}$ & ssRNA & $9.5 \mathrm{~kb}$ \\
\hline Aphid lethal paralysis virus (ALPV) & Icosahedral & $30 \mathrm{~nm}$ & $25-7-32-28 \mathrm{kDa}^{*}$ & ssRNA & $10 \mathrm{~kb}$ \\
\hline Big Sioux River virus (BSRV) & Icosahedral & $30 \mathrm{~nm}$ & $28-5-2-30 \mathrm{kDa}$ & ssRNA & $10 \mathrm{~kb}$ \\
\hline \multicolumn{6}{|c|}{ Iflaviridae } \\
\hline Deformed wing virus (DWV) & Icosahedral & $30 \mathrm{~nm}$ & $32-2-44-28 \mathrm{kDa}$ & ssRNA & $10 \mathrm{~kb}$ \\
\hline Varroa destructor virus-1 (VDV-1) & Icosahedral & $30 \mathrm{~nm}$ & $32-2-46 \mathrm{kDa}$ & ssRNA & $10 \mathrm{~kb}$ \\
\hline Egypt bee virus (EBV) & Icosahedral & $30 \mathrm{~nm}$ & $30-2-41-25 \mathrm{kDa}$ & ssRNA & $?$ \\
\hline Sacbrood virus (SBV) & Icosahedral & $30 \mathrm{~nm}$ & $31-2-32-30 \mathrm{kDa}$ & ssRNA & $9 \mathrm{~kb}$ \\
\hline Thai/Chinese sacbrood virus (TSBV) & Icosahedral & $30 \mathrm{~nm}$ & $31-2-32-30 \mathrm{kDa}$ & ssRNA & $9 \mathrm{~kb}$ \\
\hline Slow bee paralysis virus (SBPV) & Icosahedral & $30 \mathrm{~nm}$ & $27-2-46-29 \mathrm{kDa}$ & ssRNA & $5 \mathrm{~kb}$ \\
\hline \multicolumn{6}{|c|}{ Unclassified } \\
\hline Chronic bee aralysis virus (CBPV) & Anisometric & $30-60 \mathrm{~nm}$ & $23-(30 / 50 / 75 ?) \mathrm{kDa}$ & ssRNA & $23 \mathrm{~kb} / 3.7 \mathrm{~kb}$ \\
\hline Lake Sinai virus-1 (LSV-1) & $?$ & $?$ & $63 \mathrm{kDa}^{*}$ & ssRNA & $5.5 \mathrm{~kb}$ \\
\hline Lake Sinai virus-2 (LSV-2) & $?$ & $?$ & $57 \mathrm{kDa}^{*}$ & ssRNA & $5.5 \mathrm{~kb}$ \\
\hline Cloudy wing virus (CWV) & Icosahedral & $17 \mathrm{~nm}$ & $19 \mathrm{kDa}$ & ssRNA & $1.4 \mathrm{~kb}$ \\
\hline Bee virus-X (BVX) & Icosahedral & $35 \mathrm{~nm}$ & $52 \mathrm{kDa}$ & ssRNA & $?$ \\
\hline Bee virus-Y (BVY) & Icosahedral & $35 \mathrm{~nm}$ & $50 \mathrm{kDa}$ & ssRNA & $?$ \\
\hline Arkansas bee virus (ABV) & Icosahedral & $30 \mathrm{~nm}$ & $43 \mathrm{kDa}$ & ssRNA & $5.6 \mathrm{~kb}$ \\
\hline Berkeley bee picorna-like virus (BBPV) & Icosahedral & $30 \mathrm{~nm}$ & $37-?-35-32 \mathrm{kDa}$ & ssRNA & $9 \mathrm{~kb}$ \\
\hline \multicolumn{6}{|c|}{ Satellite } \\
\hline Chronic bee paralysis satellite virus (CBPSV) & Icosahedral & $17 \mathrm{~nm}$ & $15 \mathrm{kDa}$ & ssRNA & $(3 \mathrm{x})-1.11 \mathrm{~kb}$ \\
\hline \multicolumn{6}{|c|}{ Tymoviridae } \\
\hline Varroa destructor Macula-like virus (VdMLV) & Icosahedral & $30 \mathrm{~nm}$ & $24^{*} \mathrm{kDa}$ & ssRNA & $7 \mathrm{~kb}$ \\
\hline \multicolumn{6}{|c|}{ Baculoviridae } \\
\hline Apis mellifera filamentous virus (AmFV) & Rod & $150 \times 450 \mathrm{~nm}$ & $12 \times(13-70) \mathrm{kDa}$ & dsDNA & $?$ \\
\hline \multicolumn{6}{|c|}{ Iridoviridae } \\
\hline Apis iridescent virus (AIV) & Polyhedral & $150 \mathrm{~nm}$ & $?$ & dsDNA & ? \\
\hline
\end{tabular}

include the Acute Bee Paralysis Virus (ABPV), Kashmir Bee Virus (KBV), Israeli Acute Paralysis Virus (IAPV), Black Queen Cell Virus (BQCV), Chronic Bee Paralysis Virus (CBPV), Deformed Wing Virus (DWV), and Sacbrood Virus (SBV). Based on the structure and genome organization, most honey bee viruses are grouped into two families: Dicistroviridae and Iflaviridae (Bailey and
Ball, 1991; Ribière et al., 2008, Fujiyuki et al., 2004; Runckel et al., 2011).

The RNA-dependent RNA polymerases of RNA viruses lack the proofreading capability, which leads to high error rates. This results in a remarkably high evolutionary rate and a quasi-species viral population that is composed of several different genotypicvariants (Aubertetal., 2005). 


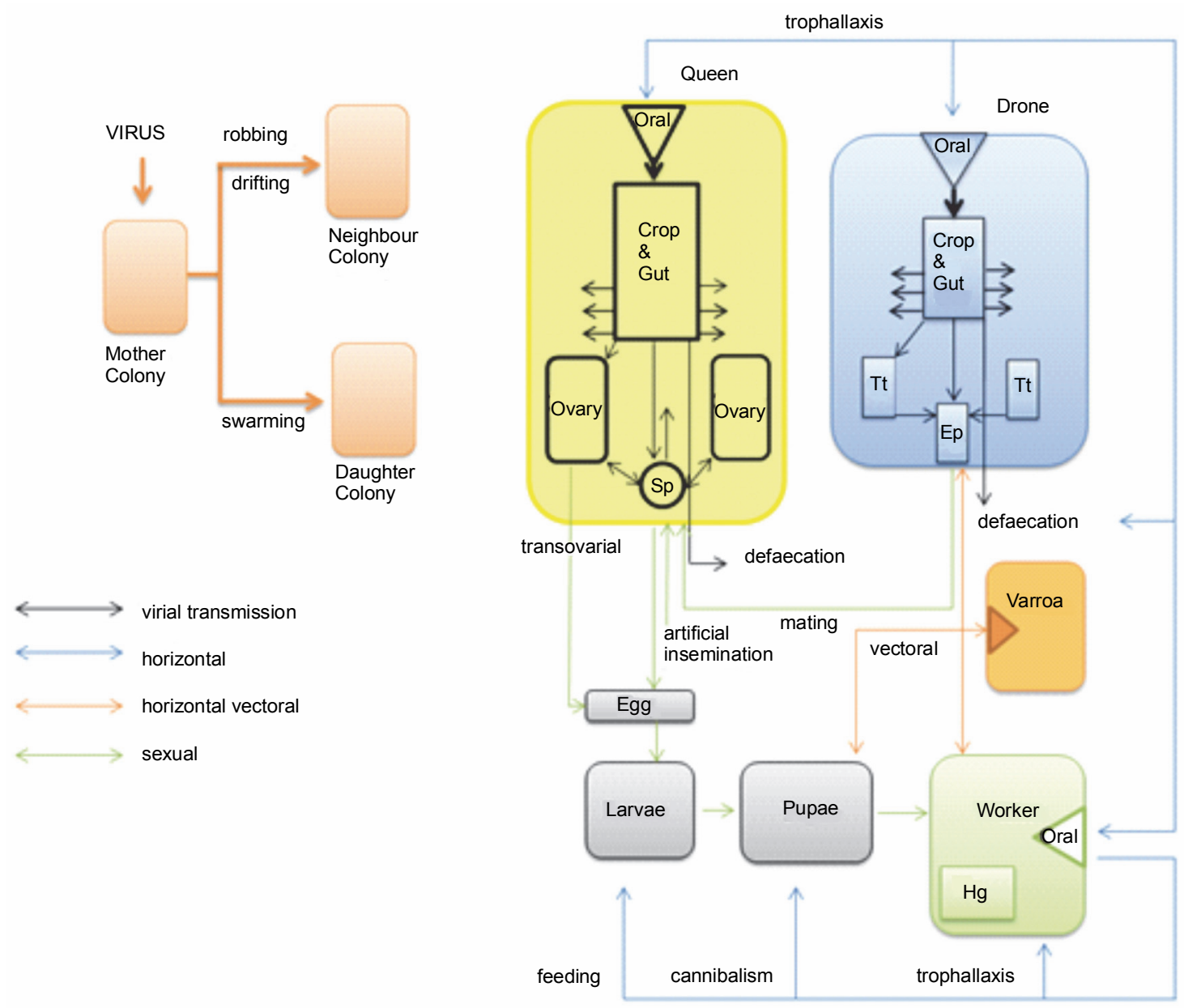

Fig. 1. Viral transmission pathway. Colony-level transmission of viruses occurs through drifting, robbing, or swarming. Within a hive, transmission between the queen, drones and workers is far more complex. Tissues are abbreviated as Ep-Endophallus, Tt-Testis, and Sp-Spermatheca. Adapted from Roy Mathew Francis (2012), Viral Diseases in Honey Bees (PhD thesis), with permission from the author

\section{Transmission}

The most crucial stage in the dynamics of virus infections is the mode of virus transmission occurring both via horizontal and vertical transmission. In horizontal transmission viruses are transmitted among individuals of the same generation, while vertical transmission occurs from adults to their offspring (Chen et al., 2006). Transmission can occur through multiple routes in social organisms. Over the past several years, horizontal transmission of honey bee viruses has been documented in bee colonies (Fig. 1). Varroa destructor mites act as vectors to transmitting the virus to uninfected bees. Viral prevalence and virus related mortality has significantly risen following the rapid spread of Varroa mites. These findings have been confirmed for Acute-Kashmir-Israeli complex (AKI) and Deformed Wing Virus (DWV) (Bo-
wen-Walker et al., 1999; Prisco et al., 2011; Dainat et al., 2012).

Bee viruses usually persist as inapparent infections and cause no overt signs of disease but they can dramatically affect honey bee health and shorten the lives of infected bees under certain conditions. Viruses can attack bees at various stages of their life, and this in turn may alter the symptoms and the outcome of the infection. Although viruses typically infect the larval or pupa stage, the symptoms are often more evident in adult bees. Viruses may be consumed in pollen or the jelly by developing bees (Fairbrother et al., 2014).

\section{Pathology and virulence}

Viruses can be classified based on the type of infection into covert and overt infections (De Miranda and 


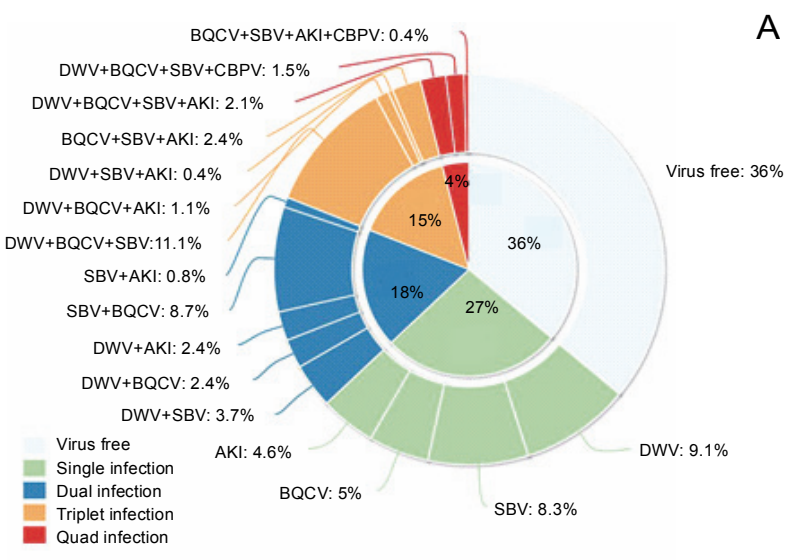

B

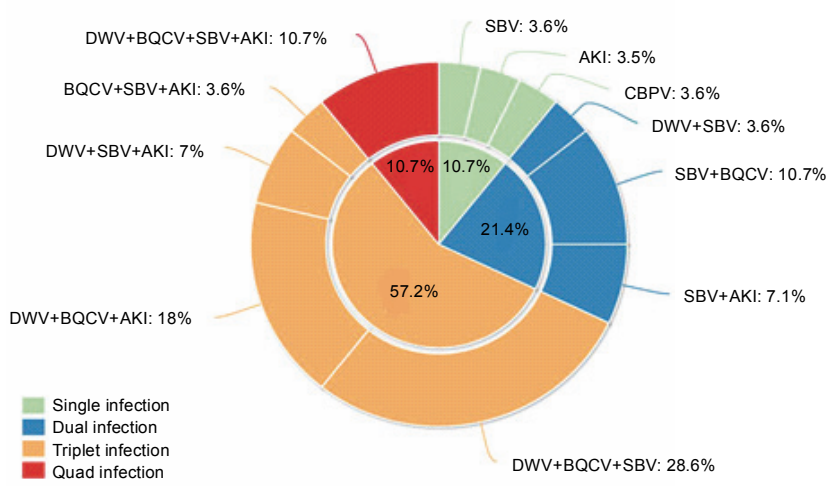

Fig. 2. Percentage of single and multiple infections in healthy colonies (A) and sick colonies (B). Reprinted from Amiri E., Meixner M., Nielsen S.L., Kryger P. (2015) Four Categories of Viral Infection Describe the Health Status of Honey Bee Colonies. PLoS ONE 10(10): e0140272; doi:10.1371/journal. pone.0140272, with permission from authors

Genersch, 2010). Although always present in colonies, viruses often persist as covert asymptomatic infections. However, if colonies are under stress, virus levels can increase causing overt infections, reduced worker longevity and brood survival, and colony loss in winter or early spring (Martin, 2001; DeGrandi-Hoffman, 2004; Doke et al., 2015).

Even without obvious observable symptoms, viruses may still affect the host adversely, although the host cells are not destroyed by the attacking virus. Further classification of covert infection is based on the viral mode of action in the host cell. For a latent infection, the viral genome is integrated with the host DNA. During a persistent infection, the viruses evade the host immune response and regulate gene expression for stable persistence. Under various stress factors covert infections may lead to overt outbreaks (Ribière et al., 2002).
Overt infections may be divided into acute and chronic. The difference lies in the duration and intensity of infection - chronic infection causes a stable but low production of viral particles over a long period, while acute infection involves the production of huge numbers of viral particles in a short time.

Honey bee colonies can suffer from multiple virus infections even if they do not show obvious pathological symptoms. Mixed virus infections in honey bees are quite widespread in nature, more than $60 \%$ of all the bees examined are infected with more than one virus. The most common pair of viruses constituting a dual infection is BQCV and DWV, and these are the two most common viruses found in bees overall (Fig. 2). While instances of multiple virus infections have been confirmed, details of the immunological effects in bees simultaneously infected with more than one virus are unknown. It is also unknown if bees experiencing multiple virus infections could facilitate an environment favorable for recombination between viruses. It is suspected that mixed virus infections lead to genetic recombination between coexisting viruses and possibly result in the creation of a new virus (Chen et al., 2004; Welsch et al., 2009; Amiriri et al., 2015).

\section{Viruses in honey bees}

Apart from the filamentous virus and the Apis iridescent virus, all honey bee viruses share similar properties with viruses within the order of Picornavirales:

1) RNA genome linked to a small protein called VPg (viral protein genome) at the $5^{\prime}$ end and polyadenylated at the $3^{\prime}$ end;

2) capsid-containing proteins organized in a module consisting of three related jelly-roll domains which form icosahedral, non-enveloped particles with a pseudo $\mathrm{T}=3$ symmetry;

3) a three-domain module containing a helicase, a cysteine protease, and an RNA-dependent RNA polymerase with the gene order Hel-Pro-Rep (Le Gall et al., 2008).

Morphologically, these viruses, with the exception of $\mathrm{CBPV}$, are very similar, showing isometric shaped protein capsids of approximately $20-30 \mathrm{~nm}$ in diameter and non-occluded (Bailey et al., 1976; Chen et al., 2005b; Baker and Schroeder, 2008). The outer part of the capsid comprises of 60 repeated protomers, each one con- 
A

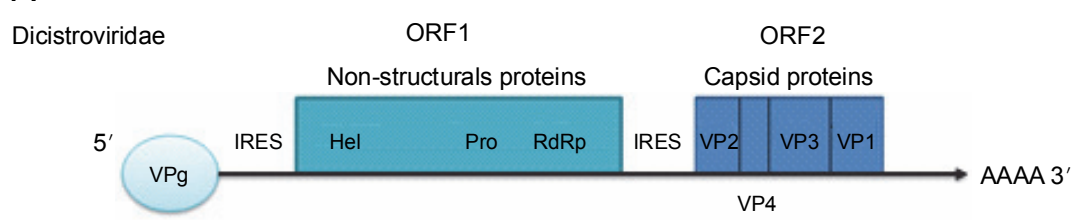

B

Iflaviridae

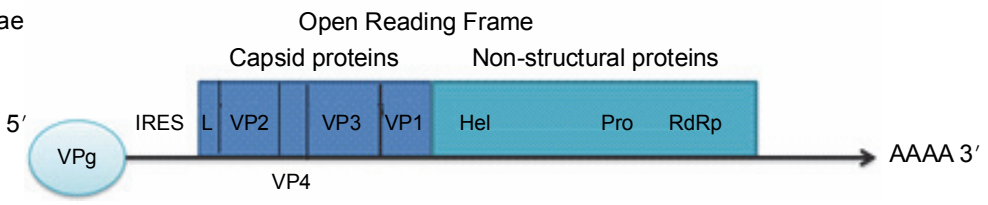

Fig. 3. Genome virus of two common families honey bee: A) Dicistroviridae and B) Iflaviridae.

$\mathrm{VPg}$ - the genome-linked viral protein; ORF1, ORF2 - open reading frames; IRES - internal ribosome entry site; Hel - helicase; Pro - protease; RdRp - RNA-dependent RNA polymerase; VP1, VP2, VP3, and VP4 - structural proteins; L - protease activity

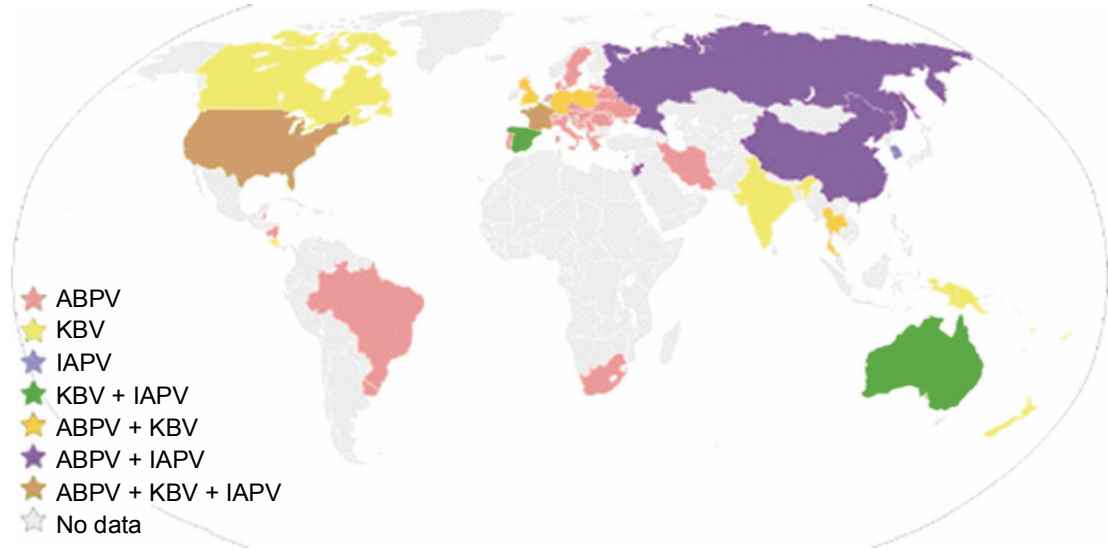

Fig. 4. World distribution of ABPV, KBV, and IAPV by country. Reprinted from Miranda J.R., Cordoni G., Budge G. (2010) The Acute Bee Paralysis Virus - Kashmir Bee Virus - Israeli Acute Paralysis Virus complex. J. Invertebr. Pathol. 103(Suppl. 1): S30-47, with permission from Elsevier

sisting of a single molecule of three subunits: VP1, VP2, and VP3. Some viruses such as BQCV and ABPV possess an additional small protein subunit VP4 that is located on the internal surface of the five-fold axis below VP1. However, the position of VP4 of CPs differs between dicistroviruses and iflaviruses (Govan et al., 2000; Leat et al., 2000).

CBPV has not yet been assigned to a particular virus genus or family because of the asymmetrical morphology of the viral particles and the co-packaging of multipartite positive-strand RNA genomes in a single virion (Olivier et al., 2008).

The viral genome is composed of a single-stranded RNA molecule coated with capsid proteins. The size of the genome of honey bee viruses, excluding the polyA tail, ranges from 8550 to 10140 nucleotides. The RNA genome is covalently attached to a small protein called
VPg (viral protein genome linked) at the $5^{\prime}$ end, and it contains a polyA tail at the $3^{\prime}$ end. VPg is important for stabilization of the $5^{\prime}$ end of the RNA genome and serves as a primer for replication and translation. At the $5^{\prime}$ end, there is a long untranslated region (UTR) containing a clover-leaf secondary structure, assumed to be involved in the initiation of translation (Tantillo et al., 2015).

Till date, complete genome sequences of seven honey bee viruses including Acute Bee Paralysis Virus (ABPV), Israeli Acute Paralysis Virus (IAPV), Kashmir Bee Virus (KBV), Black Queen Cell Virus (BQCV), Deformed Wing Virus (DWV), Sacbrood Virus (SBV), and Chronic Bee Paralysis Virus (CBPV) have been reported (Ghosh et al., 1999; Govan et al., 2000; Leat et al., 2000; de Miranda et al., 2004; Lanzi et al., 2006; Maori et al., 2007; Olivier et al., 2008). These seven viruses are considered to be the cause of the most severe diseases in 
honey bees, threatening the world beekeeping. In the following section, the overview of these major viruses is presented (Bailey and Ball, 1991).

\section{Dicistroviridae}

The genome organization of ABPV, IAPV, KBV, and BQCV is typical for the Dicistroviridae and consists of two non-overlapping open reading frames (ORFs), separated by an intergenic region (IGR) and flanked by untranslated regions (UTRs). The two ORFs are separated by an untranslated region known as the intergenic region (IGR). The $5^{\prime}$-UTR and the IGR can both initiate translation as internal ribosomal entry site (IRES). The genome of these viruses is monopartite bicistronic, with the nonstructural proteins being encoded in the $5^{\prime}$-proximal ORF and the structural proteins encoded in the 3 '-proximal ORF (Fig. 3A) (Govan et al., 2000; de Miranda et al., 2004, 2010a; Maori et al., 2007a).

\section{Acute Bee Paralysis Virus - Kashmir Bee Virus - Israeli Acute Paralysis Virus}

One of the most important groups of viruses often associated with dwindling colonies is the ABPV-KBV-IAPV complex. Viruses from this complex are closely related and show high genome similarity. They exist commonly as covert low-titer infections (Fig. 4) (De Miranda et al., 2010a).

ABPV was first discovered in 1963 (Bailey et al., 1963). The observed symptoms include paralysis, trembling, and rapid death within 1-2 days post infection. ABPV is vectored by mites (Ball, 1983; Ball, 1985) and implicated in Varroa -associated colony losses (Faucon et al., 1992; Bekesi et al., 1999; Berenyi et al., 2006). ABPV as well as KBV and CBPV are most likely transmitted contagiously between crowded live bees via the cytoplasm of broken cuticle hairs. ABPV particles have been seen in the cytoplasm of fat body cells, brain, and hypopharyngeal glands of acutely paralyzed bees (Bailey and Milne, 1969; Furgala and Lee, 1966).

KBV was first identified in adults of the eastern hive bee (Apis cerana) in the northern and western regions of India (Bailey and Woods, 1977). Bees infected with KBV have no described symptoms (Allen and Ball, 1995). KBV infects and replicates in most tissues of an infected bee, including the fore- and hindgut epithelial tissue, alimentary canal musculature, epidermis, tracheal epithelium, hemocytes, oenocytes, and tracheal end cells
(Dall, 1987). KBV seems to be the most virulent of all known honey bee viruses (Bailey et al., 1979). Varroa mites have been shown to vector KBV by exposing KBVfree pupae to varying numbers of KBV-positive mites (Chen et al., 2004a). KBV-positive mites were found to transmit KBV to pupae $70 \%$ of the time.

IAPV was first isolated in 2004 from Israeli apiaries, where it caused a significant mortality in honey bees inflicting heavy losses on Israeli apiculture (Maori et al., 2007a, 2007b; Blanchard et al., 2008). Similar to ABPV and $\mathrm{KBV}$, IAPV is strongly implicated in CCD syndrome (Cox-Foster et al. 2007) and studies have also associated IAPV with collapsing colonies (Antunez et al., 2006; Blanchard et al., 2008). Also in this case, Varroa mites are shown to be effective transmitters of the IAPV (Di Prisco et al., 2011a). The symptoms observed in bees affected with IAPV are paralysis, abnormal trembling of wings and bodies within 2-6 days post infection. IAPV replication was detected in hemolymph, brain, fat body, salivary gland, hypopharyngeal gland, gut, nerve, trachea, and muscle (Chen et al. 2014).

$\mathrm{BCQV}$ was originally isolated from dead queen larvae and pupae sealed in their cells (Bailey and Woods, 1974; Leat et al., 2000). BCQV is not known to cause largescale infections, however, epidemiological data suggest a close link with Nosema infections, making the latter more harmful. Although BQCV derives its name from its effect on developing queen pupae, it is naturally primarily distributed in adult bees (Yue et al., 2005a; Lanzi et al., 2006a). BQCV infects mid-gut tissue of adult bees. Symptoms of the viral infection include dead queen larvae or pre-pupae. In the early stage of infection larvae become yellow. The dead larvae become dark brown to black and resemble the worker bee larvae (Tantillo et al., 2015).

\section{Iflaviridae}

In contrast to the viruses from Dicistroviridae family, DWV and SBV have typical genome organization of iflaviruses, monopartite monocistronic with the structural proteins encoded in the $5^{\prime}$-proximal ORF and the non-structural proteins encoded in the 3 '-proximal ORF. The capsid proteins (CPs) are preceded by a leader sequence with undefined function. Compared to dicistroviruses, the $5^{\prime}$-UTRs of SBV and DWV are quite small and lack an IRES-like element. Both UTRs are involved in the regulation of the replication and translation of the genome (Fig. 3B) (de Miranda and Genersch, 2010b). 
DWV was first isolated from Japanese bees (Ball, 1983). DWV is associated with very characteristic symptoms of wing deformity and reduced body size (Yue et al., 2005b; Lanzi et al., 2006b) and often leads to reduced life expectancy (Yue and Genersch, 2005).

DWV has been found in all developmental stages of the bee (Chen et al., 2004b; Chen et al., 2005a; Gauthier et al., 2007) and all castes including queens, workers, and drones (Chen et al., 2005b; Gauthier et al., 2011; Yanez et al., 2012). The transmission of DWV takes place through trophallaxis between adult bees as well as between nurse bees and larvae (Chen et al., 2005a; Yue and Genersch, 2005; Chen et al., 2006b; Fievet et al., 2006; Yue et al., 2006; Möckel et al., 2011). Infection of queen offspring from infected semen by artificial insemination has been shown (de Miranda and Fries, 2008). DWV is known to be transmitted by Varroa mites (Ball, 1983) and is strongly correlated with mite infestation level in bee colonies (Bowen-Walker et al., 1999).

SBV, similar to DWV and BQCV, causes infection in bees when both young adult bees and larvae ingest the virus particles mixed in with their food. SBV most commonly accumulates in the hypopharyngeal glands of worker bees, but virus particles have also been found in the cytoplasm of fat, muscle, and tracheal end cells of larvae (Lee and Furgala, 1966). Sacbrood virus (SBV) caused the most widely distributed honey bee virus infection detected for the first time in 1913 in the USA (White, 1913). This virus can infect either larvae or adult honey bees, with a higher susceptibility of larvae to the infection. The infected larvae change their color from pearly white to pale yellow and, immediately after death, they dry out forming a dark brown ship-shaped scale (Grabensteiner et al., 2001). The adult bees develop a latent infection characterized with a decreased life span only, without acclaimed symptoms (Grabensteiner et al., 2001; Berenyi et al., 2006). The virus is accumulated in the head and especially in the hypopharyngeal glands of the infected nurse bees. The data suggest a positive correlation between the prevalence of SBV and Varroa infection.

\section{CBPV}

CBPV was first isolated in 1963 (Bailey et al., 1963; Olivier et al., 2008a, 2008b). Till date, CBPV has not been included in any family or genus. CBPV possesses different particle symmetry and size, genome composi- tion, and organization in comparison to Picornaviruses (Ribière et al., 2010). Morphologically, CBPV shows an anisometric structure, mostly ellipsoidal particles of approximately 30-65 $\mathrm{nm}$ in modal length and about $20 \mathrm{~nm}$ in width (Bailey et al., 1968; Ribière et al., 2010).

The CBPV genome contains five single-stranded RNA fragments. An analysis of CBPV sequences has shown that RNA 1 and RNA 2 encode three and four putative overlapping ORFs, respectively (Olivier et al., 2008a; Ribière et al., 2010). The ORF 3 on RNA 1 shows significant similarity with other honey viral RNA-dependent RNA polymerases (Fig. 5). This virus can persist for years as a covert infection, but may also multiply to high levels in honey bees (Blanchard et al., 2007; Ribière et al., 2007; Olivier et al., 2008) and cause an overt infection with significant losses in colonies (Allen and Ball, 1996; Olivier et al., 2008a, 2008b). The CBPV overt infection is characterized by two different syndromes that can be seen even in honey bees from the same colony (Bailey and Ball, 1991; Ribière et al., 2010). The most common one is characterized by abnormal trembling of the body and wings, bloated abdomens, and partially spread dislocated wings, which results in inability to fly. The affected honey bees die within a few days following the onset of symptoms (Ribière et al., 2007). The other syndrome is characterized by hairless, shiny, and black appearing bees, which makes them seem smaller than healthy bees, with a relatively broader abdomen. Because of their change in appearance, which makes them resemble robber bees, the affected individuals suffer nibbling attacks by healthy guard bees of their own colony. In a few days they become unable to fly, suffer trembling, and soon die.

The CBPV paralysis appears to be due to the neurotropism of the virus. CBPV particles are concentrated in sections of brain tissue, hypopharyngeal and mandibular ganglia, and in abdominal and thoracic ganglia (Giauffret et al., 1966; Olivier et al., 2008a, 2008b). CBPV infections have never been related to Varroa destructor infestations, and the virus has not been reported in this parasite (Ribière et al., 2007).

\section{Viral Infections - Detection}

\section{Nucleic acid-based assays}

Proper diagnostics is a crucial step which allows to detect infection in early stages and prevent viruses from 


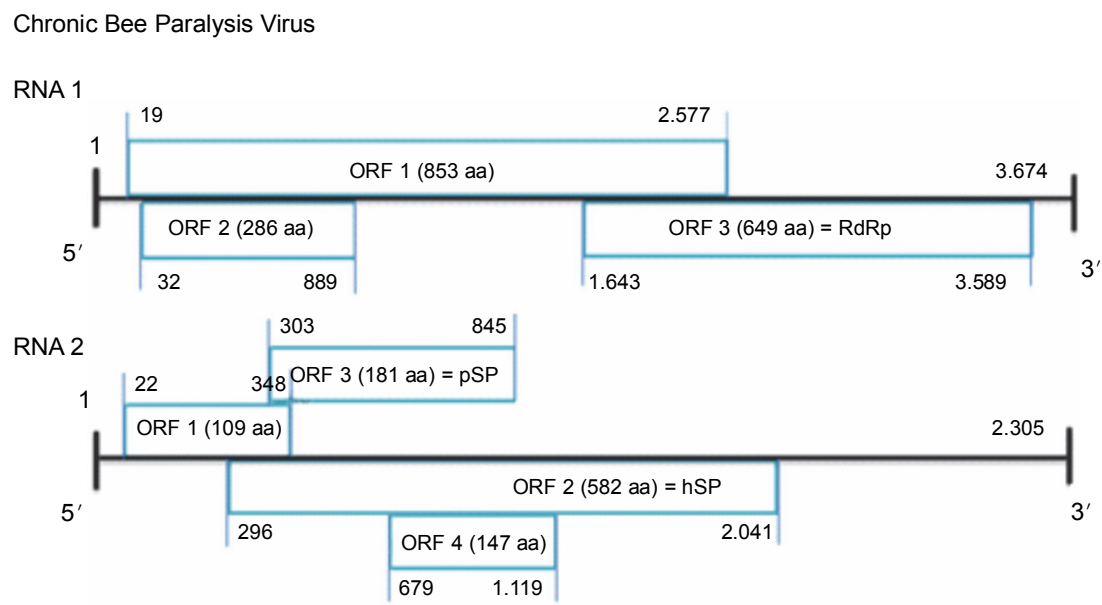

Fig. 5. Diagram of the predicted genome organization of CBPV RNA 1 (A) and RNA 2 (B). Seven putative ORFs are indicated with their positions and putative amino acid sequence length. aa - amino acid; RdRp - RNA-dependent RNA polymerase; pSP - predicted structural protein; hSP - hypothetical structural protein

spreading throughout the whole population. As genome sequences of DWV, ABPV, IAPV, KBV, BQCV, SBV, and CBPV are known (Ghosh et al., 1999; Govan et al., 2000; Leat et al., 2000; de Miranda et al., 2004; Lanzi et al., 2006; Maori et al., 2007; Reddy et al., 2013), molecular biology methods are seen as useful, sensitive, precise, and reliable diagnostic tools. Till date, a variety of diagnostic approaches have been developed. All methods described here are summarized in Table 2 and Fig. 6.

The most popular methods are RT-PCR/multiplex RT-PCR and qRT-PCR (quantitative real-time PCR). They rely on specific primers/probes and require known sequences in the target nucleic acid (Santos et al., 2004; Arya et al., 2005). Microarrays and multiplex PCR come in handy when one needs to analyze different viruses in one experiment (Wang et al., 2002; Chen et al., 2004; Liu et al., 2005; Topley et al., 2005; Glover et al., 2011; Sguazza et al., 2013).

Next-generation sequencing (NGS) is convenient for deciphering the whole genome in one approach. This method generates large data subsets in a single experiment. However, it has its limitations. Apart from long, expensive runs, NGS cannot be used to identify viruses with no homology to already known ones, and full genome sequences are difficult to obtain (especially $3^{\prime}$ and $5^{\prime}$ terminal sequences) so further sequencing is often required (Liu et al., 2011).

An interesting method involves siRNA (small interference RNA) sequencing. This approach is based on the fact that immune response in $A$. mellifera is executed, among others, via RNA interference. During viral replication, dsRNA is formed. Insect enzyme Dicer recognizes dsRNA and cleaves it into siRNAs. Another enzyme Argonaute binds antisense strand of siRNA and degrades complementary viral RNA. Sequencing of those small RNA fragments and subsequent sequence alignment gives information about the sequence of the viral genome (de Miranda et al., 2010; Chejanovsky et al., 2014).

Molecular probes labeled with fluorochromes are used in FISH technology. Probes hybridize with complementary viral sequences in situ, so not only identification of viruses but also analysis of their tissue tropism is possible (Raquin et al., 2012).

Although very useful in laboratory environment, the above methods are useless "in the field", because they require specialized equipment. The first-response diagnostics done by beekeepers in place is not possible with the use of such methods (Santos et al., 2004; Arya et al., 2005).

\section{Protein-based assays}

In serological methods such as immunodiffusion, immunofluorescence, ELISA, and Western Blot (WB), the use of antibodies or antibody fragments is necessary (instead of specific probes or primers) (Koivunen et al., 2006). Most often, required antibodies are obtained by animal immunization, however, alternative approaches like in vitro display are promising (Sidhu et al., 2006; Ullman et al., 2011; Miersch et al., 2012; Hairul Bahara et al., 2013). 
Table 2. Methods of virus identification and quantification (Glover et al., 2011; Liu et al., 2011; Topley et al., 2009; Prabha et al., 2013; Kliot et al., 2016; Grozinger et al., 2015; Blanchard et al., (2014)

\begin{tabular}{|c|c|c|}
\hline Methods & Strengths & Weaknesses \\
\hline $\begin{array}{l}\text { RT-PCR } \\
\text { (Chen et al., 2004; Squazza et al., 2013) }\end{array}$ & $\begin{array}{l}\text { - } \text { sensitive } \\
\text { - highly specific } \\
\text { - used to detect several bee viruses }\end{array}$ & $\begin{array}{l}\text { - detects only one virus per reaction } \\
\text { - requires RNA isolation } \\
\text { - requires specialized equipment }\end{array}$ \\
\hline $\begin{array}{l}\text { Real-time qRT-PCR } \\
\text { (Arya et al., 2005; Squazza et al., 2013; } \\
\text { Shen et al., 2005; Chen et al., 2005) }\end{array}$ & $\begin{array}{l}\text { - time saving (compared to RT-PCR) } \\
\text { method, } \\
\text { - specific, sensitive method } \\
\text { - allows measurement of virus concen- } \\
\text { tration and gene expression level } \\
\text { - reproducible method }\end{array}$ & $\begin{array}{l}\text { - } \text { requires RNA isolation } \\
\text { - requires specialized equipment }\end{array}$ \\
\hline $\begin{array}{l}\text { Oligonucleotide microarrays } \\
\text { (Glover et al., 2011) }\end{array}$ & - detect multiple viruses in one sample & - expensive equipment needed \\
\hline $\begin{array}{l}\text { Next-generation sequencing (NGS) } \\
\text { (Liu et al., 2011) }\end{array}$ & $\begin{array}{l}\text { - long reads (pyrosequencing) } \\
\text { - improved mapping in repetitive re- } \\
\text { gions (pyrosequencing) } \\
\text { - fast run time (pyrosequencing) } \\
\text { - most widely used platform in the } \\
\text { field (sequencing by synthesis) } \\
\text { - two-base encoding provides inherent } \\
\text { error correction (sequencing by liga- } \\
\text { tion) }\end{array}$ & $\begin{array}{l}\text { - high cost (pyrosequencing) } \\
\text { - high error rate in homopolymer re- } \\
\text { peats (pyrosequencing) } \\
\text { - low multiplexing capability of sam- } \\
\text { ples (sequencing by synthesis) } \\
\text { - long run time (sequencing by liga- } \\
\text { tion) }\end{array}$ \\
\hline $\begin{array}{l}\text { Multiplex RT-PCR } \\
\text { (Chen et al., 2004; De Smet et al., 2012) }\end{array}$ & $\begin{array}{l}\text { - } \text { simultaneous detection of several vi- } \\
\text { ruses in one reaction } \\
\text { cost-and time-efficient method (com- } \\
\text { pared to simple RT-PCR) }\end{array}$ & $\begin{array}{l}\text { - difficulties during the optimization } \\
\text { process }\end{array}$ \\
\hline $\begin{array}{l}\text { FISH } \\
\text { (Klior et al., 2016; Bishop et al., 2010) }\end{array}$ & $\begin{array}{l}\text { - visualization of viruses in live tissues } \\
\text { without complicated steps } \\
\text { - sensitive, specific method } \\
\text { - } \text { simultaneous detection of several vi- } \\
\text { ruses }\end{array}$ & $\begin{array}{l}\text { - difficulties during the optimization } \\
\text { process (multiplex FISH) } \\
\text { - limitations in resolution } \\
\text { - expensive equipment needed }\end{array}$ \\
\hline iRNA sequencing & $\begin{array}{l}\text { - } \text { simultaneous detection of several vi- } \\
\text { ruses in one reaction } \\
\text { - } \text { sensitive method } \\
\text { - meaningful data (not only for viral se- } \\
\text { quence analysis, but also in immuno- } \\
\text { defence studies) }\end{array}$ & $\begin{array}{l}\text { - } \text { sophisticated method } \\
\text { - expensive equipment needed } \\
\text { - indirect viral genome analysis } \\
\text { - siRNA coverage of virus genome is } \\
\text { unevenly distributed }\end{array}$ \\
\hline $\begin{array}{l}\text { EM (electron microscopy) } \\
\text { (Sguazza et al., 2013; Aubert et al., 2007) }\end{array}$ & $\begin{array}{l}\text { - no specific reagents are needed (me- } \\
\text { thod independent of virus type) } \\
\text { - provides structural information }\end{array}$ & $\begin{array}{l}\text { - expensive and time consuming } \\
\text { - low specificity due to similarity in } \\
\text { size and shape of viruses }\end{array}$ \\
\hline $\begin{array}{l}\text { Serological methods (ELISA, Western } \\
\text { Blot, immunodiffusion) } \\
\text { (Chen et al., 2004; Sguazza et al., 2013; } \\
\text { Aubert et al., 2007) }\end{array}$ & $\begin{array}{l}\text { - useful in detection of similar, un- } \\
\text { known viruses } \\
\text { - when modified into LFT, the } \\
\text { methods are very quick }\end{array}$ & $\begin{array}{l}\text { - } \text { require specific antibodies (produc- } \\
\text { tion may be expensive) } \\
\text { - lower specificity and sensitivity than } \\
\text { molecular methods } \\
\text { - require laboratory equipment (except } \\
\text { ready-to-use diagnostic tests) } \\
\text { - time consuming in standard format }\end{array}$ \\
\hline
\end{tabular}

Using ELISA one can estimate virus concentration in a sample, if a reference material is available (Sguazza et al., 2013). Although serological methods do not require knowledge of antigen structure or sequence, there are still drawbacks associated with their use. Serological methods are less sensitive than genetic techniques, and like nucleic acid-based detection they are usually more time consuming in a laboratory set-up, especially in formats such as ELISA or Western Blot (Sguazza et al., 2013; Aubert et al., 2007). 


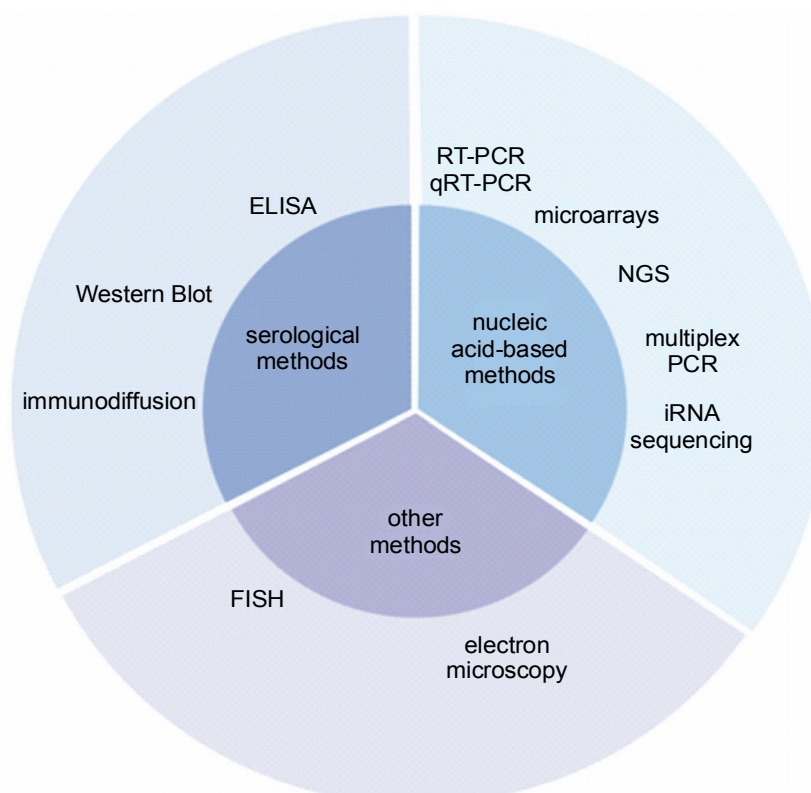

Fig. 6. The scheme of methods currently used honey bee virusesdiagnostics methods

However, when there is a requirement for a relatively fast and easy detection in the field conditions, serological methods come in handy (Shen et al., 2005), because after optimization they can give results in minutes, without the need of specialized equipment. Antibodies tested and optimized in a laboratory are often used to construct lateral flow tests useful in the field (Aubert et al., 2007). Tables 3 and 4 show examples of commercially available diagnostic tests.

As seen in Tables 3 and 4, there are several tests based on immunochromatography method using a lateral flow test (LFT) that are already available on the market. These tests allow livestock farmers to detect animal diseases immediately. Furthermore, they are faster, cheaper, and do not require specific knowledge or equipment.

There are several parameters, which are crucial for the design of a good field diagnostic test. First, it is the time from the sampling to the result. Since the point-ofcare diagnostic is meant to provide results fast, field testing should not take more than half an hour, either. For beekeeping, this would cover identification of a bee for testing, preparation of material for analysis, and performance of the analysis itself. Antibody-based assays are quite useful for this purpose, since antibodies can easily be conjugated with nanoparticles or enzymes, which in turn gives an eye-visible signal in minutes. So far this is not applicable to molecular biology methods.
Another issue in LFT development is the specificity. For diagnostics of the aforementioned viral disease there is no problem as far as the specificity in molecular biology methods goes, however, viral proteins are highly similar structurally, which can result in cross-reactivity of antibodies in protein-based methods. A highly sensitive antibody can show cross-reactivity and therefore optimization for sensitivity should also give good results.

Finally, the ease of use of the above method is also a very important issue. A good diagnostic field test should not only be provided with an understandable user's manual, but also designed in a way which will minimize the risk of incorrect use. This is also important from the point of view of the reliability of the results, since the more variations in sample preparation, the bigger the risk of false positive and false negative results. An example of pregnancy test proves that antibody assays in the LFT design allow maximal simplification of assay procedure and therefore make it accessible for all interested parties, not only laboratory staff.

All in all, a good diagnostic kit should be sensitive, specific and easy to use, give reproducible results, as well as be inexpensive, fast, and stable in long-term storage. Usually, these requirements are met by optimized serological tests as opposed to the time-consuming, expensive, laborious, and difficult to use assays based on genetic testing techniques. In many cases (Table 3 and Table 4) these requirements had been addressed and good diagnostic tools were delivered for farmers.

Although fast diagnostic tools are essential for beekeepers, there are no available solutions on the market for field recognition of many insect diseases (except of AFB and EFB diagnostic tests - Table 3). Several attempts to isolate antibodies specific towards $A$. mellifera viruses have been made, but no diagnostic test has been developed (Allen et al., 1995, Waite et al., 2003; Shen et al., 2005; Lanzi et al., 2006; Rana et al., 2011). The biggest problem with the honey bee diagnostic test development is specificity, since there is a high-protein homology between the viruses from Dicistroviridae and Iflaviridae families. Antibodies specifically recognizing $\mathrm{KBV}$, and not SBV, have been isolated (Shen et. al., $2005)$, but there is no information about their specificity towards other viruses. Again, antibodies detecting SBV have been used in the development of an ELISA kit, with which SBV detection from crude bee samples was confirmed, but no data regarding specificity are available 
Table 3. Commercial lateral flow tests for rapid diagnostics of insect diseases

\begin{tabular}{c|l|l}
\hline \multicolumn{1}{c|}{ Product, company } & \multicolumn{1}{|c}{ Disease name } & \multicolumn{1}{c}{ Comment } \\
\hline AFB Diagnostic Test Kit, Vita Ltd & American Foulbrood & $\begin{array}{l}\text { bacterial disease caused by Paenibtacillus larvae } \\
\text { subsp. larvae (Spivak et al., 2001) } \\
\text { (see: vita-europe.com). }\end{array}$ \\
\hline EFB Diagnostic Test Kit, Vita Ltd & European Foulbrood & $\begin{array}{l}\text { bacterial disease caused by Melissococcus pluto- } \\
\text { nium (Forsgren et al., 2010) } \\
\text { (see: vita-europe.com) }\end{array}$ \\
\hline
\end{tabular}

Table 4. Commercial lateral flow tests for rapid diagnostics of breeding animal diseases

\begin{tabular}{l|l|l}
\hline \multicolumn{1}{c|}{ Product, company } & Disease name & \multicolumn{1}{c}{ Comment } \\
\hline $\begin{array}{l}\text { 4D Test, Gea Farm Technologies } \\
\begin{array}{l}\text { VetExpert Rapid BoviD-4 Ag, BioNote Inc. } \\
\text { VetExpert Rapid Cryptosporidium Ag, BioNote Inc. }\end{array}\end{array}$ & Diarrhea & $\begin{array}{l}\text { calf infection caused by } E \text {. coli, rotaviru- } \\
\text { ses, coronaviruses, or cryptosporidium } \\
\text { (see: gea.com and bionote.co.kr) }\end{array}$ \\
\hline $\begin{array}{l}\text { BO-Test, Gea Farm Technologies } \\
\text { Lyme disease }\end{array}$ & $\begin{array}{l}\text { test allows to determine if tick is a Lyme } \\
\text { disease carrier } \\
\text { (see: gea.com) }\end{array}$ \\
\hline $\begin{array}{l}\text { Avian Influenza Flu Detect }{ }^{\mathrm{TM}} \text { - Type A Antigen Test, } \\
\text { Synobiotics Corp. }\end{array}$ & Avian influenza & $\begin{array}{l}\text { 16 hemagglutinin and 9 neuraminidase } \\
\text { sub-types of type A Influenza virus } \\
\text { detection } \\
\text { (see: diagnostics.zoetis.com) }\end{array}$ \\
\hline $\begin{array}{l}\text { Infectious Bursal Disease Virus Ag Test (IBDV), } \\
\text { Novazym }\end{array}$ & Gumboro Disease & $\begin{array}{l}\text { qualitative detection of virus antigen } \\
\text { IBD Ag in avian s secretions } \\
\text { (see: novazym.pl) }\end{array}$ \\
\hline $\begin{array}{l}\text { Poultry Salmonellosis Test, Novazym } \\
\text { qualitative detection of Salmonella anti- } \\
\text { gen in poultry s serum } \\
\text { (see: novazym.pl) }\end{array}$ \\
\hline
\end{tabular}

(Rana et al., 2011). Antiserum raised against DWV in rabbit showed high specificity detecting DWV, but not other viruses (Lanzi et al., 2006).

To overcome problems with specificity, in vitro selection techniques may be helpful, as conditions for antibodies selection can be strictly defined and controlled using those methods (Sidhu et al., 2006; Ullman et al., 2011; Miersch et al., 2012; Hairual et al., 2013). Specifically, one can include a step of the so called "counterselection" or negative selection in the procedure. During that stage, antibody variants recognizing similar epitopes on a homologous antigen or group of antigens are removed from the positively selected pool, leaving clones specific for the target antigen only. This strategy, unavailable during classical hybridoma approach, greatly enhances the chances of specific antibody development.

\section{Electron microscopy}

Despite being a rather sophisticated method, not suitable for routine virus detection, electron microscopy
(EM) is noteworthy. Contrary to the methods described earlier, no organism- or tissue-specific reagents are needed for the EM. Microscopy allows an initial classification of purified viruses, based on their morphology. However, this classification needs to be further confirmed with different methods (Aubert et al., 2007; Liu et al., 2011).

\section{Conclusions and prospects}

The increasing incidence of colony collapse disorders in Apis mellifera forces biotechnology industry to search for novel diagnostic tools and treatment strategies. The methods used currently allow to identify and quantify viruses in a laboratory setup only. Thus, there is a niche for inexpensive, field diagnostic tests, which would allow a rapid specific diagnosis and a quick response for infection.

In many cases laboratory testing is the last resort in the diagnosis of the colony collapse disorder. However, 
this is only an indirect way of preventing all the population from extinction. Apart from using quick and easy-touse tests that allow finding the source of a problem at an early stage, beekeepers also need effective drugs to cure insects or at least to stop the disease from spreading without destroying all apiaries. Therefore, development of tests should go hand-in-hand with establishing new treatment approaches. Immunochromatographic tests based on a lateral flow format seem to be currently the best solution to offer.

\section{References}

Allen M.F., Ball B.V. (1995) Characterization and serological relationships of strains of Kashmir bee virus. Ann. Appl. Biol. 126: 471-484.

Allen M., Ball B.V. (1996) The incidence and world distribution of honey bee viruses. Bee World 77: 141-162.

Allen M.F., Ball B.V., White R.F., Antoniw J.F. (1986) The detection of acute paralysis virus in Varroa jacobsoni by the use of a simple indirect ELISA. J. Apic. Res. 25: 100-105.

Amiri E., Meixner M., Nielsen S.L., Kryger P. (2015) Four categories of viral infection describe the health status of honey bee colonies. PLoS One, Oct 8; 10(10).

Anderson D.L., Gibbs A.J. (1988) Inapparent virus infections and their interactions in pupae of the honey bee (Apis mellifera L.) in Australia. J. Gen. Virol. 69: 1617-1625.

Anderson D.L., Trueman J.W.H. (2000) Varroa jacobsoni (Acari: Varroidae) is more than one species. Exper. Appl. Acarol. 24: 165-189.

Arya M., Shergill I.S., Williamson M., Gommersall L., Arya N., Patel H.R. (2005) Basic principles of real-time quantita tive PCR. Expert Rev. Mol. Diagn. 5: 209-219.

Aubert M., Ball B.V., Bernardinelli I., Brown M.J.F., Brown M., et al. (2005) Virology and the honey bee. European Commission, Brussels.

Aubert M., Ball B., Fries I., Moritz R., Norbert M., Iris B. (2007) Virology and the honey bee.

Bailey C. H., Thompson E.B., Castellucci V.F., Kandel E.R. (1979) Ultrastructure of the synapses of sensory neurons that mediate the gill-withdrawal reflex in Aplysia. J. Neurocytol. 8: 415-444.

Bailey L., Ball B.V. (1991) Honey bee pathology, Academic Press, London.

Bailey L., Ball B., Blanchard P., Budge G., Chejanovsky N., Chen Y., Gauthier L., Genersch E., Graaf D., Miranda J. Ribière M. et al. (2013) Standard methods for virus research in Apis mellifera. J. Apicult. Res. 52(4).

Bailey L., Ball B. V., Woods R.D. (1976) An iridovirus from bees. J. General Virol. 31: 459-461.

Bailey L., Gibbs A.J., Woods R. (1963) Two viruses from the adult honey bee (Apis mellifera Linnaeus). Virology 21: 390-395.

Bailey L., Milne R.G. (1969). The multiplication regions and interaction of acute and chronic bee-paralysis viruses in adult honey bees. J. General Virol. 4: 9-14.
Bailey L., Woods R.D. (1974) Three previously undescribed viruses from the honey bee. J. General Virol. 25: 175-186.

Bailey L, Woods R.D. (1977) Two more small RNA viruses from honey bees and further observations on Sacbrood and acute paralysis viruses. J. General Virol. 25: 175-186.

Bailey M., Muth R., Nourse H.A. (1963) Regression method for real estate price index construction. J. Amer. Statist. Assoc. 58: 933-942.

Baker A.C., Schroeder D.C. (2008) The use of RNA-dependent $R N A$ polymerase for the taxonomic assignment of picornalike viruses (order Picornavirales) infecting Apis mellifera L. populations. Virol. J. 5: 10.

Ball B.V. (1983) Thee association of Varroa jacobsoni with virus diseases of honey bees. Exper. Appl. Acarol. 19: 607-613.

Ball B.V. (1985) Acute paralysis virus isolates from honey bee colonies infected with Varroa jacobsoni. J. Apicult. Res. 24: 115-119.

Békési L., Ball B.V., Dobos-Kovács M., Bakonyi T., Rusvai M., (1999) Occurrence of acute paralysis virus of the honey bee (Apis mellifera) in a Hungarian apiary infested with the parasitic mite Varroa jacobsoni. Acta Vet. Hung. 47: 319-324.

Berenyi O., Bakonyi T., Derakhshifar I., Koglberger H., Nowotny N. (2006) Occurrence of six honey bee viruses in diseased Austrian apiaries. Appl. Environ. Microbiol. 72: 2414-2420.

Bergoin M., Colin M.E., Cousserans F., Dainat B., Gauthier L., Tentcheva D., Zappula N. (2004) Prevalence and seasonal variations of six bee viruses in Apis mellifera L. and Varroa destructor mite populations in France. Appl. Environ. Microbiol. 70: 7185-7191.

Bishop R. (2010) Applications of fluorescence in situ hybridization (FISH) in detecting genetic aberrations of medical significance. Biosci. Horiz. 3: 85-95.

Blanchard P., Carletto J., Siede R., Schurr F., Thièry R., Ribière M. (2014) Identification of Kashmir bee virus in France using a new RT-PCR method which distinguishes closely related viruses. J. Virol. Meth. 198: 82-85.

Blanchard P., Schurr F., Celle O., Cougoule N., Drajnudel P. et al. (2008) First detection of Israeli acute paralysis virus (IAPV) in France, a dicistrovirus a ecting honey bees (Apis mellifera). J. Invertebr. Pathol. 99: 348-350.

Boecking O., Genersch E. (2008) Varroosis - the ongoing crisis in bee keeping. J. Consum. Protect. Food Safety 3: 221-228.

Bowen-Walker P.L., Martin S.J., Gunn A. (1999) The transmission of Deformed wing virus between honey bees (Apis mellifera L.) by the ectoparasitic mite Varroa jacobsoni Oud. J. Invertebr. Pathol. 73: 101-106.

Buczek K. (2009) Honey bee colony collapse disorder (CCD). Lublin: Uniwersytet Przyrodniczy.

Carreck N.L., Ball B.V., Wilson J.K. (2002) Virus succession in honey bee colonies infested with Varroa Destructor. Plant \& Invertebrate Ecology Division. Apiacta 37: 44-48.

Chejanovsky N., Ophir R., Schwager M.S., Slabezki Y., Grossman S., Cos-Foster D. (2014) Characterization of viral 
siRNA populations in honey bee colony collapse disorder. Virology 454-455: 176-183.

Chen B.E., Kondo M., Garnier A., Watson F.L., PuettmannHolgado R., Lamar D.R., Schmucker D. (2006) The molecular diversity of Dscam is functionally required for neuronal wiring specificity in Drosophila. Cell 125: 607-620.

Chen Y., Zhao Y., Hammond J., Hsu H., Evans J. (2004) Multiple virus infections in the honey bee and genome divergence of honey bee viruses. J. Invertebr. Pathol. 87: 8493.

Chen Y.P., Higgins J.A., Feldlaufer M.F. (2005) Quantitative real-time reverse transcription-PCR analysis of deformed wing virus infection in the honey bee (Apis mellifera L.). Appl. Environ. Microbiol. 71: 436-441.

Chen Y.P., Pettis J.S., Collins A., Feldlaufer M.F. (2005) Prevelence and transmission of honey bee viruses. Appl. Environ. Microbiol. 1: 606-611.

Chen Y.P., Pettis J.S., Corona M., Chen W.P., Li C.J., Spivak M., Visscher P.K., DeGrandi-Hoffman G., Boncristiani H., Zhao Y., et al. (2014). Israeli acute paralysis virus: epidemiology, pathogenesis and implications for honey bee health. PLoS Pathog. Jul 31; 10(7).

Cornman R.S., Schatz M.C., Johnston J.S., Chen Y.P., Pettis J. (2010) Genomic survey of the ectoparasitic mite Varroa destructor, a major pest of the honey bee Apis mellifera. BMC Genomics 11: 602.

Cox-Foster D.L., Conlan S., Holmes E.C., Palacios G, Evans J.D. (2007) A metagenomic survey of microbes in honey bee colony collapse disorder. Science (Washington) 318: 283-286.

Dainat B., Neumann P. (2013) Clinical signs of Deformed wing virus infection are predictive markers for honey bee colony losses. J. Invertebr. Pathol. 112: 278-280.

Dall D.J. (1985) Inapparent infection of honey bee pupae by Kashmir and sac brood bee viruses in Australia. Ann. Appl. Biol. 106: 461-468.

DeGrandi-Hoffman G.C.R. (2004) A mathematical model of Varroa mite (Varroa destructor Aderson and Trueman) and honey bee (Apis mellifera L.) population dynamics. Int. J. Acarol. 30: 259-274.

De Miranda J.R., Bailey L., Ball B.V., Blanchard P., Budge G., Chejanovsky N., Chen Y.P., Gauthier L., Genersch E., De Graaf D. et al. (2013) Standard methods for virus research in Apis mellifera. J. Apicult. Res. 52.

De Miranda J.R., Cordoni G., Budge G. (2010) The Acute bee paralysis virus - Kashmir bee virus - Israeli acute paralysis virus complex. J. Invertebr. Pathol. 103: S30-S47.

De Miranda J.R., Drebot M., Tyler S., Shen M., Cameron C.E., Stolz D.B., Camazine S.M. (2004) Complete nucleotide sequence of Kashmir bee virus and comparison with acute bee paralysis virus. J. General. Virol. 85: 2263-2270.

De Miranda J.R., Fries I. (2008) Venereal and vertical transmission of deformed wing virus in honey bees (Apis mellifera L.). J. Invertebr. Pathol. 98: 184-189.

De Miranda J.R., Genersch E. (2010) Deformed wing virus. J. Invertebr. Pathol. 1: S48-61.
De Smet L., Ravoet J., De Miranda J.R., Wenseleers T., Mueller M.Y., Moritz R.F. (2012) BeeDoctor, a versatile MLPA-based diagnostic tool for screening bee viruses. PLoS One 7(10): e47953.

Doke M., Frazier M., Grozinger C.M. (2015) Overwintering honey bees: biology and management. Curr. Opin. Insect. Sci. 10: 185-193.

Giauffret A., Duthoit J.L., Caucat M.J. (1966) Etude virologique de quelques cas de maladie noire de l'abeille en France. Rec. Med. Vet. 9: 819-829.

Evans J.D., Hung A.C. (2000) Molecular phylogenetics and the classification of honey bee viruses. Arch. Virol. 145: 20152026.

Fairbrother A., Purdy J., Anderson T., Fell R. (2014) Risks of neonicotinoid insecticides to honeybees. Environ. Toxicol. Chem. 33(4): 719-731.

Faucon J.P., Vitu C., Russo P., Vignoni M. (1992) Diagnosis of acute paralysis - application to epidemic honey bee diseases in France during 1990. Apidologie 23: 139-146.

Fievet J., Tentcheva D., Gauthier L., Miranda J., Cousserans F., Colin M.E., Bergoin M. (2006) Localization of deformed wing virus infection in queen and drone Apis mellifera L. Virol. J. 3: 16.

Forsgren E. (2010) European foulbrood in honey bees. J. Invertebr. Pathol. 103(Suppl. 1): S5-9.

Fujiyuki T., Takeuchi H., Ono M., Ohka S., Sasaki T., Nomoto A et al. (2004) Novel insect picorna-like virus identified in the brains of aggressive worker honey bees. J. Virol. 78: 1093-1100.

Furgala B., Lee P.E. (1966) Acute bee paralysis virus, a cytoplasmic insect virus. Virology 29: 346-348.

Francis R.M., Nielsen S.L., Kryger P. (2013) Patterns of viral infection in honey bee queens. J. Gen. Virol. 94: 668-676.

Gauthier N.C., Monzo P., Gonzalez T., Doye A., Oldani A., Gounon P., Ricci V., Cormont M., Boquet P. (2007) Early endosomes associated with dynamic F-actin structures are required for late trafficking of $H$. pylori VacA toxin. J. Cell Biol. 23(177): 343-354.

Gauthier L., Ravallec M., Tournaire M., Cousserans F., Bergoin M. et al. (2011) Viruses associated with ovarian degeneration in Apis mellifera L. Queens. Plos One 6: e16217.

Genersch E. (2010) Honey bee pathology: current threats to honey bees and beekeeping. Appl. Microbiol. Biotechnol. 87: 87-97.

Ghosh R.C., Ball B.V., Willcocks M.M., Carter M.J. (1999) The nucleotide sequence of Sacbrood virus of the honey bee: an insect picorna-like virus. J. Gen. Virol. 80: 1541-1549.

Gliński Z., Kostro K. (2007) Colony collapse disorder - new threatening disease of the honey bee. Życie Weteryn. 82: 8.

Glover R.H., Adams I.P., Budge G., Wilkins S., Boonham N. (2011) Detection of honey bee (Apis mellifera) viruses with an oligonucleotide microarray. J. Invertebr. Pathol. 107: 216-219.

Govan V.A., Leat N., Allsopp M., Davison S. (2000) Analysis of the complete genome sequence of acute bee paralysis 
virus shows that it belongs to the novel group of insectinfecting $R N A$ viruses. Virology 277: 457-463.

Grabensteiner E., Ritter W., Carter M., Davison S., Pechhacker H., Kolodziejek J., Boecking O., Derakhshifar I., Moosbeckhofer R., Licek E. et al. (2001) Sacbrood virus of the honey-bee (Apis mellifera): Rapid identification and phylogenetic analysis using reverse transcription PCR. Clin. Diagn. Lab. Immunol. 8: 93-104.

Grozinger C.M., Robinson G.E. (2015) The power and promise of applying genomics to honey bee health. Curr. Opin. Insect. Sci. 10: 124-132.

Hairul Bahara N.H., Tye G.J., Chong Y.S., Ong E.B., Ismail A., Lim T.S. (2013) Phage display antibodies for diagnostic applications. Biologicals 41: 209-216.

Hung A.C.F., Shimanuki H., Knox D.A. (1996) Inapparent infection of acute bee paralysis virus and Kashmir bee virus in the U.S. honey bees. Am. Bee J. 136: 874-876.

Kliot A., Ghanim M. (2016) Fluorescent in situ hybridization for the localization of viruses, bacteria and other microorganisms in insect and plant tissues. Methods 98: 74-81.

Koivunen M.E., Krogsrud R.L. (2006) Principles of immunochemical techniques. Lab. Med. 37: 490-497.

Kreuze J. (2014) siRNA deep sequencing and assembly: piecing together viral infections. [in:] Detection and Diagnostics of Plant Pathogens. Ed. Gullino M.L., Bonants P.J.M. Springer: 21-38.

Lanzi G., de Miranda J.R., Boniotti M.B., Cameron C.E., Lavazza A., Capucci L., Camazine S.M., Rossi C. (2006) Molecular and biological characterization of deformed wing virus of honey bees (Apis mellifera L.). J. Virol. 80: 4998-5009.

Le Conte Y., Navajas M. (2008) Climate change: impact on honey bee populations and diseases. Rev. Sci. Tech. 27: 485-97, 499-510.

Le Gall M., De Mattei C., Giniger E. (2008) Molecular separation of two signaling pathways for the receptor. Notch. Dev. Biol. 313: 556-567.

Leat N., Ball B., Govan V., Davison S. (2000) Analysis of the complete genome sequence of black queen-cell virus, a picorna-like virus of honey bees. J. General Virol. 81: 2111-2119.

Liu S., Vijayendran D., Bonning B.C. (2011) Next generation sequencing technologies for insect virus discovery. Viruses 3: 1849-1869.

Liu W.J., Chang Y.S., Wang C.H., Kou G.H., Lo C.F. (2005) Microarray and RT-PCR screening for white spot syndrome virus immediate-early genes in cycloheximidetreated shrimp. Virology 334: 327-341.

Maori E., Lavi S., Mozes-Koch R., Gentian Y., Peretz Y., Edelbaum O., Tanne E., Sela I. (2007) Isolation and characterization of Israeli acute paralysis virus, a dicistrovirus affecting honey bees in Israel: evidence for diversity due to intra- and interspecies recombination. J. General Virol. 88: 3428-3438.

Martin S.J. (2001) The role of Varroa and viral pathogens in the collapse of honey bee colonies: a modelling approach. J. Appl. Ecol. 38: 1082-1093.
Mayolo de A., Lisby M., Erdeniz N., Thybo T., Mortenseun U.H., Rothstein R. (2006) Multiple start codons and phosphorylation result in discrete Rad52 protein species. Nucl. Acids Res. 34: 2587-2597.

Miersch S., Sidhu S.S. (2012) Synthetic antibodies: concepts, potential and practical considerations. Methods 57: 486498.

Möckel N., Gisder S., Generics E. (2011) Horizontal transmission of deformed wing virus: pathological consequences in adult bees (Apis mellifera) depend on the transmission route. J. General Virol. 92: 370-377.

Olivier V., Blancgard P., Chaouch S., Lallemand P., Schurr F., Celle O., Dubois E., Tordo N., Thiery R., Houlgatte R., Ribiere M. (2008) Molecular characterization and phylogenetic analysis of Chronic bee paralysis virus, a honey bee. Virus Res. 132: 59-68.

Ullman C.G., Frigotto L., Cooley R.N. (2011) In vitro methods for peptide display and their applications. Brief. Funct. Genomics 10: 125-134.

Prabha K., Baranwal V.K., Jain R.K. (2013) Applications of next generation high throughput sequencing technologies in characterization, discovery and molecular interaction of plant viruses. Indian J. Virol. 24: 157-165.

Di Prisco G., Pennacchio F., Caprio E., Boncristiani H.F., Evans J.D., Chen Y. (2011) Varroa destructor is an effective vector of Israeli acute paralysis virus in the honey bee, Apis mellifera. J. General Virol. 92: 151-155.

Rana R., Rana B.S., Causal N., Kumar D., Kaunda P., Rana K., Khan M.A. (2011) Identification of Sacbrood virus disease in honey bee, Apis mellifera L. by using ELISA and RTPCR techniques. Indian J. Biotechnol. 10: 274-284.

Raquin V., Wannagat M., Gouache K., Legras-Lachuer C., Moro C.V., Mavingui P. (2012) Detection of dengue group viruses by fluorescence in situ hybridization. Parasit. Vectors 5: 243

Reddy K.E., Noh J.H., Chose S.E., Kweon C.H., Yoo M.S., Doan H.T., Rama M., Yoon B.S. (2013) Analysis of the complete genome sequence and capsid region of black queen cell viruses from infected honey bees (Apis mellifera) in Korea. Virus Genes 47: 126-132.

Ribière M., Ball B.V., Aubert M.F.A. (2008) Natural history and geographic distribution of honey bee viruses. Virology and the Honey Bee. $\mathrm{VI}^{\text {th }}$ Framework. EC Publications, Brussels: 15-84.

Ribière M., Lallemand P., Iscache A.L., Schurr F., Celle O., Blanchard P., Olivier V., Faucon J.P. (2007) Spread of infectious chronic bee paralysis virus by honey bee (Apis mellifera L.) feces. Amer. Soc. Microbiol. 23: 7711-7716.

Ribière M., Olivier V., Blanchard P. (2010) Chronic bee paralysis: A disease and a virus like no other?J. Invertebr. Pathol. 103: S120-S131.

Ribière M., Triboulot C., Mathieu L., Aurieres C., Faucon J.P. et al. (2002) Molecular diagnosis of chronic bee paralysis virus infection. Apidologie 33: 339-351.

Runckel C., Flenniken M.L., Engel J.C., Ruby J.G., Ganem D., Andino R. (2011) Temporal analysis of the honey bee 
microbiome reveals four novel viruses and seasonal prevalence of known viruses, Nosema, and Crithidia. PLoS ONE 6: e20656.

Sammataro D., Gerson U., Needham G. (2000) Parasitic mites of honey bees: life history, implications, and impact. Ann. Rev. Entomol. 45: 519-548.

Santos C.F.D., Sakai V.T., Machado M.A. de A.M., Schippers D.N., Greene A.S. (2004) Reverse transcription and polymerase chain reaction: principles and applications in dentistry. J. Appl. Oral Sci. 12: 1-11.

Scott-Dupree C. D., McCarthy J. (1995) Honey bee viruses. Bee Cult. 123: 392-396.

Sguazza G.H., Reynaldi F.J., Galosi C.M., Pecoraro M.R. (2013) Simultaneous detection of bee viruses by multiplex PCR. J. Virol. Meth. 194: 102-106.

Shen M., Cui L., Ostiguy N., Cox-Foster D. (2005) Intricate transmission routes and interactions between picorna-like viruses (Kashmir bee virus and Sacbrood virus) with the honey bee host and the parasitic Varroa mite. J. Gen. Virol. 86: 2281-2289.

Shen M., Yang X., Cox-Foster D., Cui L. (2005) The role of Varroa mites in infections of Kashmir bee virus (KBV) and deformed wing virus $(D W V)$ in honey bees. Virology 342: 141-149.

Sidhu S.S., Fellouse F.A. (2006) Synthetic therapeutic antibodies. Nat. Chem. Biol. 2: 682-688.

Singh R., Levitt A.L., Rajotte E.G., Holmes E.C., Ostiguy N. (2010) RNA viruses in hymenopteran pollinators: evidence of inter-taxa virus transmission via Pollen and potential impact on non-apis hymenopteran species. PLoS ONE 5(12).

Spivak M., Reuter G. (2001) Resistance to American foulbrood disease by honey bee colonies Apis mellifera bred for hygienic behavior. Apidologie 32: 555-565.

Strachecka A., Demetraki-Paleolod J. (2011) System proteolityczny powierzchni ciała Apis mellifera $w$ zachowaniu zdrowotności rodzin pszczelich. Kosmos 60: 290-291.
Tantillo G., Bottaro M., Di Pinto A., Martella V., Di Pinto P., Terio V. (2015) Virus infections of honey bees Apis mellifera. Ital. J. Food Sci. 4(3): 157-168.

Topley E.L. (2009) Molecular detection and characterisation of RNA viruses of honey bees. University of the Western Cape: $\mathrm{PhD}$ thesis.

Topley E., Davison S., Leat N., Benjeddou M. (2005) Detection of three honey bee viruses simultaneously by a single Multiplex Reverse Transcriptase PCR. Afr. J. Biotechnol. 4: 763-767.

Waite R., Thompson H., Brown M., Watkins M., Bew M. (2003) Preliminary studies into novel detection methods for honey bee pathogens. XXXVIII Congress Apimondi.

Wang D., Coscoy L., Zylberberg M., Avila P.C., Boushey H.A., Ganem D., DeRisi J.L. (2002) Microarray-based detection and genotyping of viral pathogens. Proc. Natl. Acad. Sci. USA 99: 15687-15692.

Welch A., Drummond F., Tewari S., Averill A., Burand J.P. (2009) Presence and prevalence of viruses in local and migratory honey bees (Apis mellifera) in Massachusetts. Appl. Environ. Microbiol. 75(24): 7862-7865.

White G.F. (1913) Sacbrood, a disease of bees. Circular No. 169, Bureau of Entomology.

Yanez O., Jaffe R., Jarosch A., Fries I., Moritz R.F.A. et al. (2012) Deformed wing virus and drone mating lights in the honey bee (Apis mellifera): implications for sexual transmission of a major honey bee virus. Apidologie 43: 17-30.

Yue C., Genersch E. (2005) RT-PCR analysis of Deformed wing virus ( $D W V$ ) in bees (Apis mellifera) and mites (Varroa destructor). J. General Virol. 86: 3419-3424.

Yue C., Schroder M., Bienefeld K., Generics E. (2006) Detection of viral sequences in semen of honey bees (Apis mellifera): Evidence for vertical transmission of viruses through drones. J. Invertebr. Pathol. 92: 105-108. 